\title{
The Florida Department of Agriculture and Consumer Services (FDACS) Continuing Education Unit (CEU) System for Certified Pesticide Applicators ${ }^{1}$
}

\section{Frederick M. Fishel ${ }^{2}$}

This guide provides an update of the amended Continuing Education Unit system used by FDACS for recertifying pesticide applicators.

Applicators must become recertified in order to renew their pesticide applicator licenses. To become recertified, individuals have the option of either retaking the certification exams or earning CEUs. CEU credits are earned by attending professional meetings or seminars or completing online or correspondence courses that have been approved in advance by FDACS to award CEUs.

If an individual has more than one license, the same CEUs can be used to renew both licenses, provided the CEUs were earned during the license period for each license (from the day the license was issued until it expires) or within one year after expiration.

In rare situations, reexamination is required for recertification, with no option of using CEUs. FDACS will notify any applicator affected by this requirement.

\section{CEUs Required}

Before January 1, 2005. All applicators who renewed their licenses with CEUs before January 1, 2005, were required to earn the number of CEUs shown in Table 1 for each category that was being renewed. If licensed in more than one category, the applicator must have earned the total number of CEUs required for all categories being renewed. Of the number of CEUs required for each primary category, at least 2 of those CEUs were required to be Core CEUs, and at least half of the CEUs required had to be approved for that specific category. The remaining CEUs required could have been approved for either Core or the specific category. The same Core CEUs could not be applied to more than one category. If the applicator was licensed in more than one primary category, earning 2 core CEUs per category would have been required. For example, applicators licensed in Aquatic and Right-of-Way were required to accumulate $16 \mathrm{CEUs}$ for Aquatic and 8 CEUs for Right-of-Way. In renewing the Aquatic category, the applicator must have accumulated at least 2 Core CEUs, plus at least 8

1. This document is PI-40, one of a series of the Pesticide Information Office, Florida Cooperative Extension Service, Institute of Food and Agricultural Sciences, University of Florida. Original publication date April 2005. Visit the EDIS Web Site at http://edis.ifas.ufl.edu.

2. Frederick M. Fishel, Associate Professor, Agronomy Department, and Director, Pesticide Information Office; Florida Cooperative Extension Service, Institute of Food and Agricultural Sciences, University of Florida, Gainesville, FL 32611.

The Institute of Food and Agricultural Sciences (IFAS) is an Equal Opportunity Institution authorized to provide research, educational information and other services only to individuals and institutions that function with non-discrimination with respect to race, creed, color, religion, age, disability, sex, sexual orientation, marital status, national origin, political opinions or affiliations. U.S. Department of Agriculture, Cooperative Extension Service, University of Florida, IFAS, Florida A. \& M. University Cooperative Extension Program, and Boards of County Commissioners Cooperating. Larry Arrington, Dean 
Aquatic CEUs, plus 6 additional CEUs that were approved for either Core or Aquatic. To renew the Right-of-Way category, the applicator would have needed an additional 2 Core CEUs (not the same Core CEUs used for Aquatic category), plus at least 4 Right-of-Way CEUs, plus 2 additional CEUs approved for either Core or Right-of-Way.

After January 1, 2005. Applicators who renew their licenses with CEUs after January 1, 2005, must have 4 Core CEUs plus the number of category CEUs shown in the table below. Only 4 Core CEUs are required per license - not 4 Core CEUs per category.

Beginning in 2005, all category CEUs must be approved for the specific category. There will no longer be a requirement for having 2 Core CEUs per primary category, and Core CEUs can no longer be used to meet the required number of category CEUs. Example: After January 1, 2005, private applicators must earn 4 Core CEUs plus 4 CEUs approved for the Private Applicator Agriculture category. No substitutions of other types of CEUs will be allowed.

No Core CEUs are required and cannot be used to renew secondary categories. The only secondary category is Demonstration and Research. To renew the Demonstration and Research category, the license holder must earn 4 CEUs approved for Demonstration and Research (no Core CEUs).

\section{Aerial CEUs}

The Aerial license is classified as a primary category. The aerial category issued under the authority of Chapter 487, Florida Statutes, is for agricultural and related applications and is not valid for public health aerial (mosquito control, etc.) applications.

Aerial applicators licensed in only the aerial category are licensed to simply apply pesticides according to the directions of another person who has made the pest management decisions. Aerial applicators who make determinations of when treatments are needed or which pesticides to apply must be licensed in the appropriate work-related category or categories (agricultural row crop, agricultural tree crop, forestry, etc.) in addition to the aerial category.
Aerial applicators licensed only in the agricultural aerial category are not authorized to make ground application of restricted use pesticides. Applicators must be licensed in the appropriate ground categories (agricultural row crop, agricultural tree crop, forestry, etc.) to make ground application of restricted use pesticides to these sites.

Aerial License Renewal. Aerial applicators must earn 4 Core CEUs plus 16 Aerial CEUs to renew the Aerial category - no substitutions allowed.

\section{Using a Combination of CEUs and Exams to Renew}

Applicators may recertify by re-taking and passing the certification exams if they do not have enough CEUs for renewal. If an applicator has earned the required category CEUs but not enough Core CEUs, the Core exam may be re-taken. Applicators may also choose to re-take the category exam(s) providing 4 Core CEUs have been earned, regardless of the number of categories being renewed.

Applicators who are licensed in more than one category may choose to renew some categories with CEUs and other categories by exam.

Example 1: Private applicators are required to have 4 Core CEUs plus 4 CEUs approved for the Private Applicator Agriculture category. A private applicator who has 4 Private Applicator CEUs and only 2 Core CEUs may choose to re-take the Core exam instead of earning 2 additional Core CEUs, if desired.

Example 2: A commercial applicator licensed in both the Agricultural Row Crop category and the Agricultural Tree Crop category has earned $8 \mathrm{Ag}$ Row Crop CEUs, 2 Ag Tree Crop CEUs, and 3 Core CEUs. The applicator will need to earn 6 more Ag Tree Crop CEUs plus 1 more Core CEU. To recertify in both categories, the applicator has the option of re-taking the Ag Tree Crop and Core exams instead of earning additional CEUs, or take either of those exams and earn the required CEUs for the other. 


\section{Additional Information}

FDACS Agricultural Pesticides Certification and

Compliance Program:

http://www.safepesticideuse.com/

University of Florida Pesticide Information

Office: http://pested.ifas.ufl.edu/

Order exam study manuals:

http://www.ifasbooks.ufl.edu/merchant2/

Table 1. Lists the number of CEUs required for applicators who choose to recertify with CEUs. Effective January 1, 2005, all applicators must earn 4 Core CEUs in addition to the category CEUs listed below.

\begin{tabular}{||l|c||}
\hline \hline Primary Categories & Number of Category CEUs Required \\
\hline Aerial & 16 \\
\hline Agricultural Animal Pest Control & 4 \\
\hline Agricultural Row Crop Pest Control & 8 \\
\hline Agricultural Tree Crop Pest Control & 8 \\
\hline Antifouling Boat Paint Application & 4 \\
\hline Aquatic Pest Control & 16 \\
\hline Forest Pest Control & 8 \\
\hline Chlorine Gas Infusion & 4 \\
\hline Natural Areas Weed Management & 16 \\
\hline Ornamental \& Turf Pest Control & 12 \\
\hline Private Applicator Agricultural Pest & 4 \\
Control & \\
\hline Raw Agricultural Commodity Fumigation & 4 \\
\hline Regulatory Inspection \& Sampling & 4 \\
\hline Regulatory Pest Control & 12 \\
\hline Right-of-Way Pest Control & 8 \\
\hline Seed Treatment & 4 \\
\hline Sewer Root Control & 4 \\
\hline Soil \& Greenhouse Fumigation & 4 \\
\hline Wood Treatment & 4 \\
\hline Secondary Category & 4 \\
\hline Demonstration \& Research & Number of Category CEUs Required \\
\hline \hline
\end{tabular}

